Research Paper

\title{
Hemolysis in patients with Extracorporeal Membrane Oxygenation therapy for severe Acute Respiratory Distress Syndrome - a systematic review of the literature
}

\author{
Lorenz A. Materne1, Oliver Hunsicker ${ }^{1,2}$, Mario Menk ${ }^{1,2,3}$, Jan A. Graw ${ }^{1,2,3 凶}$ \\ 1. Department of Anesthesiology and Operative Intensive Care Medicine CCM/CVK, Charité - Universitätsmedizin Berlin, corporate member of Freie \\ Universität Berlin, Humboldt-Universität zu Berlin, and Berlin Institute of Health. \\ 2. ARDS/ECMO Centrum Charité, Charité - Universitätsmedizin Berlin, Berlin, Germany. \\ 3. Berlin Institute of Health (BIH), Berlin, Germany.
}

$\triangle$ Corresponding author: Jan A. Graw, MD. Department of Anesthesiology and Intensive Care Medicine, Charité - Universitätsmedizin Berlin, Campus Virchow Klinikum, Augustenburger Platz 1, 13353 Berlin, Germany. Tel. +49 (30) 450 551119; Fax: +49 (30) 450 551909; E-mail: jan-adriaan.graw@charite.de.

(1) The author(s). This is an open access article distributed under the terms of the Creative Commons Attribution License (https://creativecommons.org/licenses/by/4.0/). See http://ivyspring.com/terms for full terms and conditions.

Received: 2020.07.02; Accepted: 2020.12.19; Published: 2021.02.18

\begin{abstract}
The Acute Respiratory Distress Syndrome (ARDS) is common in patients on the Intensive Care Unit and associated with significant mortality rates. In situations of severe respiratory insufficiency and failure of all possible conservative therapeutic approaches, veno-venous extracorporeal membrane oxygenation (VV ECMO) is used as a final option for temporary replacement of pulmonary function. ARDS as well as sepsis and VV ECMO treatment are all associated with intravascular hemolysis. The extent and relevance of intravascular hemolysis in the context of ARDS therapy is unclear. This systematic review aims to summarize the current evidence on the incidence and associated complications of intravascular hemolysis in adult patients with ARDS and treatment with VV ECMO. The databases MEDLINE, EMBASE and Web of Science were systematically searched and 19 publications fulfilled inclusion criteria. The incidence of hemolysis in patients with ARDS and treatment with VV ECMO ranged from 0 to $41 \%$ with survivors showing lower incidences and less severe hemolysis. A pump head thrombosis and high blood flows $(\geq 3 \mathrm{l} / \mathrm{min})$ as well as use of dual-lumen cannulas but not different pump models were associated with increased hemolysis. In conclusion, intravascular hemolysis in patients with ARDS and treatment with VV ECMO is a common and relevant complication that appears associated with increased mortality. Apart from ECMO hardware-settings, no additional possible causes for increased red cell breakdown such as disease severity, duration of ECMO therapy, or number and quality of red blood cell transfusions were investigated. Further research is needed to determine the origin and relevance of intravascular hemolysis in patients with ARDS and treatment with VV ECMO.
\end{abstract}

Key words: veno-venous ECMO; ARDS; cell-free hemoglobin; hemolysis; ECMO-system; pump head thrombosis

\section{Introduction}

The severe Acute Respiratory Distress Syndrome (ARDS), a disease of all age groups and associated with a high mortality, leads to death in $46 \%$ of cases with conventional therapy [1,2]. Although data are still poor, veno-venous extracorporeal membrane oxygenation (VV ECMO) has become a frequent rescue therapy in recent years [2-5]. Therapy with VV ECMO secures oxygenation and decarboxylation and facilitates a lung-protective ventilation strategy to buy time for the recovery of the lungs or as a bridge to a lung transplant [6-8]. During VV ECMO therapy venous blood is drained through a large bore cannula into an extracorporeal circuit. A pump drives the blood through a membrane oxygenator and finally oxygenated and decarboxylated blood is infused back into a large vein of the circulation [8].

Intravascular hemolysis is a known side effect of blood circulating through extracorporeal systems and membrane oxygenators [5]. Current literature reports an incidence of approximately $18 \%$ in patients treated with ECMO. However, these data include venovenous and veno-arterial ECMO-systems (VA ECMO) [5]. There are only few studies reporting the incidence of hemolysis and potential hemolysis-associated side effects in patients treated exclusively with VV ECMO. In addition, accumulating evidence suggests a role of 
hemolysis in sepsis and ARDS where an increased plasma concentration of cell-free hemoglobin might be associated with an increased mortality and adverse clinical effects [9-11]. Plasma hemoglobin scavenges endothelial-derived nitric oxide (NO) thereby inducing vasoconstriction and concomitant hypertension [12]. Furthermore, cell-free hemoglobin releases the highly reactive heme molecule, which oxidizes proteins and lipids, induces oxidative stress, and triggers proinflammatory signaling pathways [13, 14].

In this systematic review the current evidence on the incidence of hemolysis in adult patients with ARDS and treatment with VV ECMO is investigated. Furthermore, the evidence on potential associations between intravascular hemolysis, morbidity and mortality, ECMO-settings, and ECMO-hardware is analyzed.

\section{Materials and Methods}

\section{Search strategy}

We included all studies with data on hemolysis in patients treated with VV ECMO.

The databases MEDLINE (Medical Literature Analysis and Retrieval System Online) and Web of Science were systematically searched using the reference management software EndNote X7 (Thomson Reuters) on September 30, 2019. In addition, the database EMBASE (Excerpta Medica dataBASE) was searched using Ovid (Ovid Technologies) on the same day. Publications were screened by the following search terms: ["ECMO" OR "extracorporeal support" OR "extracorporeal life support" OR "ECLS" OR "extracorporeal membrane oxygenation"] AND ["plasma haemoglobin" OR "cell-free haemoglobin" OR "free haemoglobin" OR "haptoglobin" OR "hemolysis"]. Duplicates were detected and deleted by EndNote and manually.

\section{Inclusion and exclusion criteria}

All studies found by the above mentioned inclusion criteria were included into further analysis. The following exclusion criteria were applied in a top down hierarchic strategy (Fig. 1): 1) Case reports, comments, editorials, conference abstracts and reports, book chapters and letters to the editor were excluded from further analysis. Reviews, meta-analyses and all non-English papers were also excluded. 2) All non-human, experimental studies were excluded. 3) Studies in pediatric patients (patients aged $<18$ years) were excluded. 4 ) Studies on extracorporeal systems other than ECMO such as hemodialysis and cardiopulmonary bypass were excluded. 5) Studies including only treatment with VA ECMO were excluded. 6) Finally, all publications not providing information on hemolysis specifically in VV ECMO patients were excluded. Decisions were made based on the title and the abstract of each study meeting the search terms. For all studies where a clear decision was impossible after reading the abstract, the full text was analyzed. Furthermore, in unclear cases, decisions were made only after agreement and discussion between two independent reviewers.

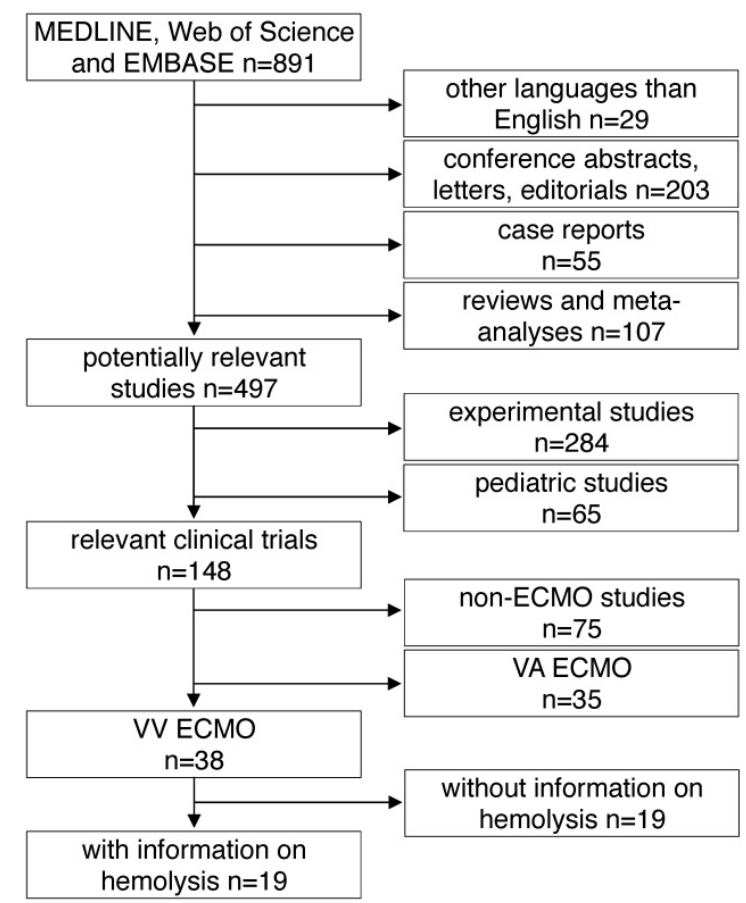

Figure 1. Study flow diagram. MEDLINE: Medical Literature Analysis and Retrieval System Online, EMBASE: Excerpta Medica dataBASE, VA ECMO: veno-arterial extracorporeal membrane oxygenation, VV ECMO: veno-venous extracorporeal membrane oxygenation.

\section{Data extraction}

Full texts of all included studies were analyzed. For studies including patients with VV ECMO and VA ECMO therapy, characteristics of the whole study population treated with ECMO were discussed. If not provided in the papers, the following values were calculated from reported data: percentage of male patients, underlying disease and indication for ECMO therapy, proportion of patients with VV ECMO therapy, pump model, mode of cannulation, pump head thrombosis, and time on ECMO. If possible, incidence of hemolysis was reported or calculated. All data on $\mathrm{fHb}$-measurements were converted to $\mathrm{mg} / \mathrm{dl}$. In addition, ECMO circuit characteristics such as pump flow, details of cannulas, pump model, and occurrence of pump head thrombosis were analyzed.

\section{Assessment of systematic reporting}

The included studies were screened for information on systematic reporting strategies such as STROBE or CONSORT $[15,16]$. 


\section{Results}

A total of 891 articles met the search criteria and were screened in detail (Fig. 1). There were 497 original articles with 284 papers describing findings of non-clinical, experimental studies and 65 studies that were exclusively performed in pediatric patients.
Thirty-eight of the remaining 148 clinical studies reported data on veno-venous extracorporeal organ support. Of these 38 studies, 19 studies reported data on hemolysis in patients treated with VV ECMO including data of 7,707 VV ECMO applications (Table 1).

Table 1. Characteristics of the included studies

\begin{tabular}{|c|c|c|c|c|c|c|c|c|c|c|c|}
\hline \multirow[b]{2}{*}{ Author [year] } & \multirow[b]{2}{*}{$\begin{array}{l}\text { Place of study, } \\
\text { Study type }\end{array}$} & \multirow[b]{2}{*}{ 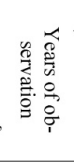 } & \multicolumn{7}{|c|}{ Study population } & \multirow[b]{2}{*}{ 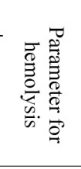 } & \multirow[b]{2}{*}{ Endpoints } \\
\hline & & & $\begin{array}{l}\text { No. of } \\
\text { ECMO } \\
\text { patients } \\
\text { (ECMO } \\
\text { runs) }\end{array}$ & $\begin{array}{l}\text { No. of } \\
\text { vvECMO } \\
(\%)\end{array}$ & $\begin{array}{l}\text { Age } \\
\text { (years) }\end{array}$ & $\begin{array}{l}\text { Gender, No. } \\
\text { of men }(\%)\end{array}$ & & Indication for $\mathrm{ECMO} \mathrm{( \% )}$ & $\begin{array}{l}\text { Time on ECMO } \\
\text { (days) }\end{array}$ & & \\
\hline $\begin{array}{c}\text { Chan (26) } \\
{[2010]}\end{array}$ & $\begin{array}{l}\text { Hong Kong, } \\
\text { multi-center, } \\
\text { ORS }\end{array}$ & $\begin{array}{c}2009- \\
10\end{array}$ & 7 & $7(100)$ & $\begin{array}{c}42 \\
(39-50)^{\mathrm{a}}\end{array}$ & $\begin{array}{c}2 \\
(29)\end{array}$ & 100 & H1N1-induced ARDS & $6(6-10)^{a}$ & $\mathrm{n} / \mathrm{a}$ & $\begin{array}{l}\text { - review of VV ECMO in Hong } \\
\text { Kong } \\
\text { - hospital survival } \\
\text { - respiratory function and support }\end{array}$ \\
\hline $\begin{array}{l}\text { Petersen (22) } \\
\quad[2011]\end{array}$ & $\begin{array}{l}\text { Denmark, } \\
\text { single-center, } \\
\text { ORS }\end{array}$ & $\begin{array}{c}2009- \\
10\end{array}$ & 9 & $8(88.9)^{\mathrm{b}}$ & $\begin{array}{c}47.8^{\mathrm{b}} \\
(26-65)^{\mathrm{c}}\end{array}$ & $\begin{array}{c}5 \\
(55.6)^{\mathrm{b}}\end{array}$ & 100 & H1N1-induced ARDS & $\begin{array}{c}16.4^{\mathrm{b}} \\
(11-29)^{\mathrm{c}}\end{array}$ & $\mathrm{Hb}$ & $\begin{array}{l}\text { - ICU and 90-day survival } \\
\text { - days on ECMO or mechanical } \\
\text { ventilation }\end{array}$ \\
\hline $\begin{array}{l}\text { Chimot (19) } \\
\text { [2013] }\end{array}$ & $\begin{array}{l}\text { France, } \\
\text { multi-center, } \\
\text { survey, ORS }\end{array}$ & $\begin{array}{c}2009- \\
11\end{array}$ & $\mathrm{n} / \mathrm{a}(52)^{\mathrm{d}}$ & $52(100)$ & $\begin{array}{c}45.3 \\
( \pm 17.8)^{\mathrm{e}}\end{array}$ & $\begin{array}{l}32^{\mathrm{f}} \\
(61.54)^{\mathrm{f}}\end{array}$ & $\begin{array}{l}77 \\
13^{\mathrm{f}} \\
10^{\mathrm{f}}\end{array}$ & $\begin{array}{l}\text { ARDS } \\
\text { CF with hypercapnic failure } \\
\text { other }\end{array}$ & $8( \pm 7)^{\mathrm{e}, \mathrm{g}}$ & $\mathrm{Hb}$ & $\begin{array}{l}\text { - Avalon cannula insertion and size } \\
\text { - Avalon cannula performance } \\
\text { - Avalon cannula imaging methods }\end{array}$ \\
\hline $\begin{array}{l}\text { Guirand (27) } \\
\text { [2014] }\end{array}$ & $\begin{array}{l}\text { USA, } \\
\text { multi-center }^{\mathrm{h}} \text {, } \\
\text { ORS }\end{array}$ & $\begin{array}{c}2001- \\
09\end{array}$ & 26 & $26(100)$ & $\begin{array}{c}33.0 \\
( \pm 11.5)^{\mathrm{e}}\end{array}$ & $20(77)$ & 100 & $\begin{array}{l}\text { trauma with severe respiratory } \\
\text { failure }\end{array}$ & $9.33( \pm 9.46)^{\mathrm{e}, \mathrm{i}}$ & $\mathrm{fHb}$ & $\begin{array}{l}\text { - survival to discharge } \\
\text { - ICU and hospital LOS } \\
\text { - total ventilator days }\end{array}$ \\
\hline $\begin{array}{c}\text { Kutlesa (28) } \\
\quad[2014]\end{array}$ & $\begin{array}{l}\text { Croatia, } \\
\text { single-center, } \\
\text { ORS }\end{array}$ & $\begin{array}{c}2009- \\
13\end{array}$ & 17 & $17(100)$ & $\begin{array}{c}43 \\
(23-74)^{c}\end{array}$ & $\begin{array}{c}12 \\
(71)\end{array}$ & 100 & H1N1-induced ARDS & $\begin{array}{c}8.0 \\
(6.5-13.9)^{\mathrm{a}, \mathrm{i}}\end{array}$ & fHb & $\begin{array}{l}\text { - variables associated with in- } \\
\text { hospital mortality }\end{array}$ \\
\hline $\begin{array}{l}\text { Lehle (29) } \\
\text { [2014] }\end{array}$ & $\begin{array}{l}\text { Germany, } \\
\text { single-center, } \\
\text { ORS }\end{array}$ & $\begin{array}{c}2009- \\
12\end{array}$ & 186 & $186(100)$ & $\begin{array}{c}47.3 \\
( \pm 16.7)^{\mathrm{e}}\end{array}$ & $\begin{array}{c}119 \\
(63.98)^{\mathrm{b}}\end{array}$ & 100 & acute lung failure & $9(4-67)^{a}$ & $\mathrm{fHb}$ & $\begin{array}{l}\text { - flow dynamics of different } \\
\text { ECMO-systems } \\
\text { - relevance of hemolysis }\end{array}$ \\
\hline $\begin{array}{l}\text { Lubnow (30) } \\
\quad[2014]\end{array}$ & $\begin{array}{l}\text { Germany, } \\
\text { single-center, } \\
\text { ORS }\end{array}$ & $\begin{array}{c}2009- \\
13\end{array}$ & $265(265)$ & $265(100)$ & $\begin{array}{c}50 \\
(36-60)^{\mathrm{a}}\end{array}$ & $\begin{array}{l}175 \\
(66)^{b}\end{array}$ & $\begin{array}{l}57 \\
20 \\
12 \\
11\end{array}$ & $\begin{array}{l}\text { primary lung failure } \\
\text { sepsis with secondary lung } \\
\text { failure } \\
\text { trauma with ARDS } \\
\text { other }\end{array}$ & $9(6-15)^{a}$ & $\begin{array}{l}\mathrm{fHb} \\
\mathrm{LDH}\end{array}$ & $\begin{array}{l}\text { - technical complications during } \\
\text { VV ECMO } \\
\text { - relevance of technical complica- } \\
\text { tions as predictor for a system } \\
\text { exchange }\end{array}$ \\
\hline $\begin{array}{l}\text { Lehle (31) } \\
{[2015]}\end{array}$ & $\begin{array}{l}\text { Germany, } \\
\text { single-center, } \\
\text { ORS }\end{array}$ & $\begin{array}{c}2009- \\
14\end{array}$ & 318 & $318(100)$ & $\begin{array}{c}52 \\
(38-61)^{\mathrm{a}}\end{array}$ & $\begin{array}{l}212 \\
(66.7)^{\mathrm{b}}\end{array}$ & $\begin{array}{l}57 \\
19 \\
10 \\
13\end{array}$ & $\begin{array}{l}\text { primary lung failure } \\
\text { secondary lung failure } \\
\text { trauma with ARDS } \\
\text { other }\end{array}$ & $13.03^{\mathrm{j}}(\mathrm{n} / \mathrm{a})$ & $\begin{array}{l}\mathrm{fHb} \\
\mathrm{LDH}\end{array}$ & $\begin{array}{l}\text { - incidence of hemolysis } \\
\text { - reasons for hemolysis } \\
\text { - effect of high fHb on mortality }\end{array}$ \\
\hline $\begin{array}{c}\text { Omar (23) } \\
{[2015]}\end{array}$ & $\begin{array}{l}\text { USA, } \\
\text { single-center, } \\
\text { ORS }\end{array}$ & $\begin{array}{c}2007- \\
13\end{array}$ & 154 & $28^{\mathrm{k}}(18)$ & 51 & $\begin{array}{c}116 \\
(75.3)^{\mathrm{b}}\end{array}$ & $\begin{array}{l}29.3 \\
12.2 \\
11.6 \\
10.9 \\
36.0^{\mathrm{b}}\end{array}$ & $\begin{array}{l}\text { cardiomyopathy } \\
\text { cardiac surgery } \\
\text { post MI cardiogenic shock } \\
\text { respiratory failure } \\
\text { other }\end{array}$ & $\begin{array}{l}\text { survivors: } \\
4( \pm 3.5)^{\mathrm{e}} \\
\text { deceased: } \\
6.4( \pm 7.6)^{\mathrm{e}}\end{array}$ & $\begin{array}{l}\mathrm{fHb} \\
\mathrm{LDH}\end{array}$ & $\begin{array}{l}\text { - predictors for mortality (in- } \\
\text { hospital mortality and long-time } \\
\text { survival) } \\
\text { - successful weaning from ECMO } \\
\text { (survival }>48 \mathrm{~h} \text { after ECMO) }\end{array}$ \\
\hline $\begin{array}{c}\text { Malfertheiner } \\
\text { (17) } \\
{[2016]}\end{array}$ & $\begin{array}{l}\text { Germany, } \\
\text { single-center, } \\
\text { RCT }\end{array}$ & $\begin{array}{c}2011- \\
13\end{array}$ & 54 & $54(100)$ & $\begin{array}{c}52 \\
(41-63)^{\mathrm{a}}\end{array}$ & $\begin{array}{c}28 \\
(51.9)^{\mathrm{b}}\end{array}$ & $\begin{array}{l}85.2^{\mathrm{b}} \\
5.6^{\mathrm{b}} \\
9.3^{\mathrm{b}}\end{array}$ & $\begin{array}{l}\text { pneumonia } \\
\text { trauma }(>48 \mathrm{~h} \text { before ECMO) } \\
\text { other }\end{array}$ & $\begin{array}{c}13.5 \\
(4-70)^{\mathrm{c}}\end{array}$ & $\begin{array}{l}\mathrm{fHb} \\
\mathrm{LDH}\end{array}$ & $\begin{array}{l}\text { - hemostatic changes during therapy } \\
\text { with different ECMO-systems }\end{array}$ \\
\hline $\begin{array}{c}\text { Pan }(24) \\
{[2016]}\end{array}$ & $\begin{array}{l}\text { Australia, } \\
\text { single-center, } \\
\text { ORS }\end{array}$ & $\begin{array}{c}2010- \\
14\end{array}$ & $177(184)$ & $56(30.4)^{1}$ & $\begin{array}{c}\text { normal }^{\mathrm{m}}: \\
49.0(35-58)^{\mathrm{a}}, \\
\text { low level }{ }^{\mathrm{n}}: \\
46.0(33-55)^{\mathrm{a}} \text {, } \\
\text { high level }{ }^{\circ}: \\
41.5(33.5- \\
57)^{\mathrm{a}}\end{array}$ & $\begin{array}{l}\text { normal }^{\mathrm{m}}: \\
37(60.7)^{\mathrm{p}} \\
\text { low level } \\
69(69.7)^{\mathrm{p}} \\
\text { high level } \\
12(50.0)^{\mathrm{p}}\end{array}$ & $\begin{array}{l}36.4^{1} \\
20.7^{1} \\
20.1^{1} \\
17.4^{1} \\
5.4^{1}\end{array}$ & $\begin{array}{l}\text { cardiogenic shock } \\
\text { bridge-to-transplant (HTX or } \\
\text { LuTX) } \\
\text { acute pneumonia } \\
\text { cardiac arrest } \\
\text { other }\end{array}$ & $\begin{array}{c}\text { normal }^{\mathrm{m}}: \\
4.6(3.5-7.8)^{\mathrm{a}, \mathrm{i}}, \\
\text { low level } \mathrm{l}^{\mathrm{n}}: \\
7.0(4.4-11.2)^{\mathrm{a}, \mathrm{i}}, \\
\text { high level }{ }^{\mathrm{O}}: \\
7.3(5.8-14.1)^{\mathrm{a}, \mathrm{i}}\end{array}$ & $\mathrm{fHb}$ & $\begin{array}{l}\text { - frequency of patients with elevat- } \\
\text { ed fHb } \\
\text { - reasons for system changes } \\
\text { - association of fHb levels with in- } \\
\text { hospital mortality }\end{array}$ \\
\hline $\begin{array}{c}\text { Kon }(21) \\
{[2017]}\end{array}$ & $\begin{array}{l}\text { worldwide, } \\
\text { ELSO- } \\
\text { register, } \\
\text { multi-center, } \\
\text { ORS }\end{array}$ & $\begin{array}{c}2009- \\
13\end{array}$ & $\mathrm{n} / \mathrm{a}(717)$ & $591(82.4)^{1}$ & $\begin{array}{l}\text { vv: } 44.0 \\
(28-56)^{\mathrm{a}} \\
\text { va: } 37.5 \\
(25-51)^{\mathrm{a}}\end{array}$ & $\begin{array}{l}\text { vv: } 536 \\
(90.7)^{p} \\
\text { va: } 98 \\
(77.8)^{p}\end{array}$ & 100 & acute respiratory failure & $\begin{array}{l}\text { vv: } 7.8(4.0-13.6)^{\mathrm{a}}, \\
\text { va: } 5.5(2.9-11.1)^{\mathrm{a}}\end{array}$ & $\mathrm{n} / \mathrm{a}$ & $\begin{array}{l}\text { - comparing va to VV ECMO in } \\
\text { patients with severe respiratory } \\
\text { failure and hypotension }\end{array}$ \\
\hline $\begin{array}{l}\text { Lorusso (32) } \\
\quad[2017]\end{array}$ & $\begin{array}{l}\text { worldwide, } \\
\text { ELSO- } \\
\text { register, } \\
\text { multi-center, } \\
\text { ORS }\end{array}$ & $\begin{array}{l}1992- \\
2015\end{array}$ & $\begin{array}{c}4988 \\
(4988)\end{array}$ & $4988(100)$ & $\begin{array}{c}46 \\
(32-58)^{\mathrm{a}}\end{array}$ & $2969(59.2)$ & 100 & respiratory failure & $\begin{array}{l}\text { no CNS injury: } 10.8 \\
( \pm 11.5)^{\mathrm{e}, \mathrm{i}}, \\
\text { CNS injury: } \\
10.7( \pm 15.4)^{\mathrm{e}, \mathrm{i}}\end{array}$ & $\mathrm{fHb}$ & $\begin{array}{l}\text { - prevalence of CNS injury } \\
\text { - types of CNS injury } \\
\text { - in-hospital survival } \\
\text { - factors associated with CNS injury }\end{array}$ \\
\hline $\begin{array}{l}\text { Brechot (33) } \\
\quad[2018]\end{array}$ & $\begin{array}{l}\text { France, } \\
\text { single-center, } \\
\text { ORS }\end{array}$ & $\begin{array}{c}2008- \\
12\end{array}$ & 157 & $157(100)$ & $\begin{array}{l}\text { MERT: } 44 \\
(32-55)^{\mathrm{a}} \\
\text { ICU: } 50(38- \\
58)^{\mathrm{a}}\end{array}$ & $\begin{array}{l}\text { MERT: } 68 \\
\text { (57.6), } \\
\text { ICU: } 29 \\
(74.4)\end{array}$ & 100 & $\begin{array}{l}\text { severe acute respiratory fail- } \\
\text { ure }\end{array}$ & $\begin{array}{l}\text { MERT: } \\
9(4-24)^{\mathrm{a}} \\
\text { ICU: } \\
10(6-21)^{\mathrm{a}}\end{array}$ & $\mathrm{fHb}$ & $\begin{array}{l}\text { - comparing MERT and ICU im- } \\
\text { planted VV ECMO: indications, } \\
\text { outcomes and characteristics }\end{array}$ \\
\hline $\begin{array}{l}\text { Hoshino (34) } \\
\quad[2018]\end{array}$ & $\begin{array}{l}\text { Japan, } \\
\text { single-center, } \\
\text { ORS }\end{array}$ & $\begin{array}{c}2014- \\
16\end{array}$ & 10 & $10(100)$ & $\begin{array}{c}62 \\
( \pm 10)^{\mathrm{e}}\end{array}$ & $\begin{array}{c}9 \\
(90)^{\mathrm{b}}\end{array}$ & 100 & acute pulmonary failure & $10( \pm 13)^{\mathrm{e}}$ & $\mathrm{n} / \mathrm{a}$ & $\begin{array}{l}\text { - coagulation and fibrinolysis mark- } \\
\text { ers as predictors for ECMO circuit } \\
\text { exchange }\end{array}$ \\
\hline $\begin{array}{l}\text { Mazzeffi (35) } \\
\quad[2018]\end{array}$ & $\begin{array}{l}\text { worldwide, } \\
\text { ELSO- } \\
\text { Register, } \\
\text { multi-center, } \\
\text { ORS }\end{array}$ & $\begin{array}{c}2011- \\
16\end{array}$ & 744 & $744(100)$ & $\begin{array}{l}\text { 27Ch: } \\
45( \pm 16)^{\mathrm{e}} \\
31 \mathrm{Ch}: \\
46( \pm 14)^{\mathrm{e}}\end{array}$ & $\begin{array}{l}27 \mathrm{Ch}: \\
150(40.3) \\
\text { 31Ch: } \\
193(51.9)\end{array}$ & $\mathrm{n} / \mathrm{a}$ & & $\begin{array}{c}\text { 27Ch: } \\
6.9(3.6-14.8)^{\mathrm{a}, \mathrm{i}} \\
31 \mathrm{Ch}: \\
7.7(3.9-15.1)^{\mathrm{a}, \mathrm{i}}\end{array}$ & $\mathrm{fHb}$ & $\begin{array}{l}\text { - rate of ICH, hemolysis, cannula } \\
\text { complications and in-hospital } \\
\text { mortality in patients with } 27 \text { and } \\
\text { 31Ch dual-lumen cannula }\end{array}$ \\
\hline
\end{tabular}




\begin{tabular}{|c|c|c|c|c|c|c|c|c|}
\hline $\begin{array}{c}\text { Bosma (25) } \\
{[2019]}\end{array}$ & $\begin{array}{l}\text { Netherlands, } \\
\text { single-center, } \\
\text { ORS }\end{array}$ & $\begin{array}{c}2016- \\
17\end{array}$ & 56 & $18(32.1)$ & $\begin{array}{c}57 \\
(22-79)^{\mathrm{c}}\end{array}$ & $\begin{array}{c}35 \\
(62.5)\end{array}$ & $\begin{array}{l}42.9^{b} \\
17.9^{b} \\
8.9^{b} \\
30.4^{b}\end{array}$ & $\begin{array}{l}\text { post-cardiotomy } \\
\text { pneumonia } \\
\text { cardiac arrest } \\
\text { other }\end{array}$ \\
\hline $\begin{array}{c}\text { Deatrick (18) } \\
\text { [2019] }\end{array}$ & $\begin{array}{c}\text { USA, } \\
\text { single-center, } \\
\text { RCT }\end{array}$ & $\begin{array}{c}2016- \\
17\end{array}$ & 10 & $10(100)$ & $44(34-53)^{\mathrm{a}}$ & $\mathrm{n} / \mathrm{a}$ & $\begin{array}{l}60^{\mathrm{b}} \\
20^{\mathrm{b}} \\
20^{\mathrm{b}}\end{array}$ & $\begin{array}{l}\text { pneumonia } \\
\text { ARDS post op/trauma } \\
\text { other }\end{array}$ \\
\hline $\begin{array}{c}\text { Fisser (20) } \\
\text { [2019] }\end{array}$ & $\begin{array}{l}\text { Germany, } \\
\text { single-center, } \\
\text { ORS }\end{array}$ & $\begin{array}{c}2010- \\
17\end{array}$ & $172^{q}$ & $172(100)$ & $\begin{array}{l}\text { thrombosis: } \\
53.3( \pm 13.5)^{\mathrm{e}} \text {, } \\
\text { no thrombosis: } \\
51.0( \pm 12.1)^{\mathrm{e}}\end{array}$ & $\begin{array}{l}\text { thrombosis: } \\
66(62), \\
\text { no throm- } \\
\text { bosis: } \\
35(53)^{\mathrm{e}}\end{array}$ & $\begin{array}{l}77.3^{\mathrm{b}} \\
14.0^{\mathrm{b}} \\
1.2^{\mathrm{b}} \\
7.6^{\mathrm{b}}\end{array}$ & $\begin{array}{l}\text { pulmonal } \\
\text { extrapulmonal } \\
\text { traumatic } \\
\text { other }\end{array}$ \\
\hline
\end{tabular}

\begin{tabular}{|c|c|c|}
\hline $9(2-35)^{\mathrm{c}}$ & $\begin{array}{l}\text { fHb, } \\
\text { H-index, } \\
\text { LDH }\end{array}$ & $\begin{array}{l}\text { - evaluating the suitability and } \\
\text { reliability of the H-index in pa- } \\
\text { tients on ECMO }\end{array}$ \\
\hline $11.5(7.1-16.2)^{\mathrm{a}, \mathrm{i}}$ & $\begin{array}{l}\text { fHb, } \\
\text { LDH }\end{array}$ & $\begin{array}{l}\text { - comparing body-weight adapted } \\
\text { and aPTT targeted UFH infusion } \\
\text { - oxygenator/circuit exchange } \\
\text { - hemolysis and bleeding episodes }\end{array}$ \\
\hline $\begin{array}{l}\text { thrombosis: } 12.3 \\
\qquad( \pm 8.1)^{\mathrm{e}} \\
\text { no thrombosis: } \\
13.6( \pm 12.3)^{\mathrm{e}}\end{array}$ & $\mathrm{fHb}$ & $\begin{array}{l}\text { - incidence of and risk factors for } \\
\text { cannula-related thrombosis after } \\
\text { VV ECMO }\end{array}$ \\
\hline
\end{tabular}

a: interquartile range, $\mathbf{b}$ : mean or percentage calculated for the given number of ECMO patients, $\mathbf{c}$ : range, $\mathbf{d}: 52$ cannula uses were reported, e: standard deviation, f: percentage calculated for 52 cannula uses, $\mathbf{g}$ : time on cannula, $\mathbf{h}$ : all ECMO Patients were treated in one hospital, $\mathbf{i}$ : days were calculated from hours, $\mathbf{j}$ : mean calculated from the given data for 318 patients, $\mathbf{k}$ : number calculated from the given percentage of vvECMO patients, $\mathbf{l}$ : percentage calculated for the given number of ECMO runs, $\mathbf{m}$ : fHb-plasma level $<10 \mathrm{mg} / \mathrm{dl}(\mathrm{n}=61)$, $\mathbf{n}: \mathrm{fHb}$-plasma level $10-50 \mathrm{mg} / \mathrm{dl}(\mathrm{n}=99)$, $\mathbf{o}: \mathrm{fHb}$-plasma level $>50 \mathrm{mg} / \mathrm{dl}(\mathrm{n}=24)$, $\mathbf{p}$ : percentage calculated for the number of ECMO runs in this subgroup, $\mathbf{q}$ : number of patients screened for venous thrombosis

ECMO: extracorporeal membrane oxygenation, VV ECMO: veno-venous ECMO, ORS: observational retrospective study, H1N1: influenza virus subtype, ARDS acute respiratory distress syndrome, n/a: not applicable, Hb: hemoglobin, ICU: intensive care unit, CF: cystic fibrosis, Avalon cannula: dual-lumen cannula in vvECMO, fHb: plasma free hemoglobin, LOS: length of stay, LDH: lactate dehydrogenase, MI: myocardial infarction, RCT: randomized controlled trial, HTX: heart transplant, LuTX: lung transplant, ELSO: Extracorporeal Life Support Organization, va: veno-arterial, CNS: central nervous system, MERT: mobile ECMO retrieval team, Ch: Charrière, ICH: intracranial hemorrhage, H-index: hemolysis index, aPTT: activated Partial Thrombo-plastin Time, UFH: unfractionated heparin

\section{Basic study characteristics}

Table 1 gives an overview of the 19 studies that were included in this systematic review. There were only two randomized, prospective but non-blinded trials including a total of 64 patients [17, 18]. Data collection of all other studies occurred retrospectively. Chimot and colleagues used a survey to collect retrospective data and attained responses from 18 out of the 19 contacted institutes [19]. Of the included studies only Fisser et al. stated that they made use of a systematic reporting strategy and provided a STROBE statement [20].

Seventeen of the 19 included studies represent a total of 7,350 patients ranging from 7 to 4,988 patients per study. The two other studies reported data on ECMO runs $(n=769)[19,21]$. There were fife studies that included patient populations treated with both, va and VV ECMO [21-25]. Fourteen studies analyzed patient cohorts that were exclusively treated with $\mathrm{VV}$ ECMO [17-20, 26-35].

\section{Incidence of hemolysis during therapy with VV ECMO}

In fourteen of the included studies, hemolysis was quantified using plasma concentrations of cell-free hemoglobin (fHb) (Table 1) [17, 18, 20, 23-25, 27-33, 35]. In addition, six of the studies reported plasma activity of lactate dehydrogenase (LDH) [17, $18,23,25,30,31]$. To quantify hemolysis, Bosma et al. defined a hemolysis-index (H-index) that significantly correlated with plasma levels of $\mathrm{fHb}$ [25]. The $\mathrm{H}$-index was automatically measured with every clinical chemistry blood analysis by absorbance measurements of the blood sample at different wavelengths by high throughput analyzers used in the authors' institution [25].

Six of the included studies did not report the incidence of hemolysis $[17,18,20,23,29,34]$. Moreover, it was not possible to calculate the incidence of hemolysis from the published data. In the remaining studies the reported or calculated hemolysis-incidence ranged from 0 to $41 \%$ (Table 2).

The two prospective, randomized studies were among the studies not reporting the incidence of hemolysis. However, Malfertheiner et al. noted a median $\mathrm{fHb}$-plasma concentration of $54 \mathrm{mg} / \mathrm{dl}$ on the last day of ECMO therapy [17]. On the day after ending ECMO therapy, plasma concentrations of $\mathrm{fHb}$ and LDH-activity decreased significantly [17]. The second prospective, randomized study by Deatrick and colleagues reported normal $\mathrm{fHb}$ plasma concentrations but elevated LDH-activity without clear quantification [18]. The retrospective study by Fisser et al. stated a mean concentration of $\mathrm{fHb}>50$ $\mathrm{mg} / \mathrm{dl}$ during ECMO treatment in both of the analyzed groups [20]. Many of the included authors recognize measurements of $\mathrm{fHb}$-concentration $>50$ $\mathrm{mg} / \mathrm{dl}$ to define hemolysis $[27,28,32,35]$.

\section{Hemolysis and mortality}

The studies of Kutlesa et al. and Omar et al. found a higher incidence of hemolysis in nonsurvivors $(80-83 \%)$ compared to survivors $(0-18 \%)$ (Table 2) $[23,28]$. From the data published by Chan et al. and Petersen et al. higher incidences of hemolysis could be calculated for non-survivors compared to survivors [22, 26]. Similarly, in 2015 Lehle et al. reported that the average maximum plasma concentration of cell-free hemoglobin was significantly higher in non-survivors compared to survivors [31]. The remaining studies did not report data on mortality in patients treated with VV ECMO with regard to increased plasma concentrations of cell-free hemoglobin (Table 2). 


\section{Hemolysis and pump head thrombosis}

Table 3 shows the studies that report pump head thromboses of the ECMO-system and their association with hemolysis. In 2014, Lehle and colleagues described a patient who had a fHb-plasma concentration greater than $100 \mathrm{mg} / \mathrm{dl}$ caused by a pump head thrombosis [29]. Furthermore, in 2015, the same group reported 8 pump head thromboses that were associated with hemolysis [31]. Of note, after exchange of the pump head the increased plasma concentration of cell-free hemoglobin decreased within two days [31]. Lubnow and colleagues reported 13 pump head thrombosis, all associated with an increase of hemolysis parameters cell-free hemoglobin and LDH-activity [30]. In 6 of the patients the plasma concentration of cell-free hemoglobin was already elevated on the day before the pump head thrombosis occurred [30]. Pan and colleagues reported five events of a pump head thrombosis which all was associated with hemolysis and occurred exclusively during therapy with VV ECMO [24]. Bosma et al. reported a rise of the H-index when a pump head thrombosis occurred [25].

\section{Hemolysis and blood flow, cannulation and ECMO-system}

Lehle and coworkers reported in 2014 that they could not find a causal link between an increase in blood flow and an increase in the plasma concentrations of cell-free hemoglobin [29]. However, in 2015 the same working group reported a minimal but significant increase in $\mathrm{fHb}$-plasma concentrations when blood flows $\geq 3 \mathrm{l} / \mathrm{min}$ were applied (Table 3 ) [31]. Furthermore, fHb-plasma concentrations were greater in patients treated with dual-lumen NovaPort24Ch-cannulas compared to larger dual-lumen cannula models (Table 3) [31]. Mazzeffi et al. investigated patients treated with 27 and 31Ch duallumen cannulas showing no significant difference in fHb-plasma concentrations [35].

There was no association between increased hemolysis and the usage of a specific ECMO-system (Table 3). Of note, the diagonal pump Deltastream of Medos operating with a rotational speed twice as high compared to centrifugal pumps did not cause a relevant increase of fHb-plasma concentrations [17, 29, 31]. All but one working group of those who reported data on the pump models that were used, utilized second-generation centrifugal pumps. Solely Guirand and colleagues applied roller pumps [27].

Table 2. Incidence of hemolysis in VV ECMO

\begin{tabular}{|c|c|c|c|c|c|}
\hline Study [year] & $\begin{array}{l}\text { Definition of } \\
\text { hemolysis } \\
\mathrm{fHb}[\mathrm{mg} / \mathrm{dl}] \\
\mathrm{LDH}[\mathrm{U} / \mathrm{l}]\end{array}$ & $\begin{array}{c}\text { Time of } \\
\text { measurement }\end{array}$ & Incidence of hemolysis (n) & Hemolysis before ECMO & $\begin{array}{l}\text { Impact of hemolysis } \\
\text { on } \\
\text { mortality }\end{array}$ \\
\hline $\begin{array}{c}\text { Chan (26) } \\
{[2010]}\end{array}$ & $\mathrm{n} / \mathrm{a}$ & $\mathrm{n} / \mathrm{a}$ & $2(28.6 \%)^{a}$ & $\mathrm{n} / \mathrm{a}$ & $\begin{array}{l}\text { hemolysis in de- } \\
\text { ceased: } 1(100 \%)^{\mathrm{a}} \text {, } \\
\text { in survivors: } 1(17 \%)^{\mathrm{a}}\end{array}$ \\
\hline $\begin{array}{l}\text { Petersen (22) } \\
\quad[2011]\end{array}$ & $\mathrm{n} / \mathrm{a}$ & daily & $1(12.5 \%)^{b}$ & $\mathrm{n} / \mathrm{a}$ & $\begin{array}{l}\text { hemolysis in de- } \\
\text { ceased: } 1(33 \%)^{\mathrm{b}} \text {, } \\
\text { in survivors: } 0(0 \%)^{\mathrm{b}}\end{array}$ \\
\hline $\begin{array}{c}\text { Chimot (19) } \\
\text { [2013] }\end{array}$ & $\begin{array}{l}\text { blood transfusion require- } \\
\text { ment/decrease of Hb with } \\
\text { no other explanation }\end{array}$ & $\mathrm{n} / \mathrm{a}$ & $11(21 \%)$ & $\mathrm{n} / \mathrm{a}$ & $\mathrm{n} / \mathrm{a}$ \\
\hline $\begin{array}{l}\text { Guirand (27) } \\
\text { [2014] }\end{array}$ & $\mathrm{fHb}>50$ & $\mathrm{n} / \mathrm{a}$ & $0(0 \%)$ & $\mathrm{n} / \mathrm{a}$ & $\mathrm{n} / \mathrm{a}$ \\
\hline $\begin{array}{l}\text { Kutlesa (28) } \\
\quad[2014]\end{array}$ & $\mathrm{fHb}>50$ & $\mathrm{n} / \mathrm{a}$ & $\begin{array}{l}7(41 \%) \\
\text { (these patients all required pump head exchange } \\
\text { or change of the complete ECMO-system) }\end{array}$ & $\mathrm{n} / \mathrm{a}$ & $\begin{array}{l}\text { hemolysis in de- } \\
\text { ceased: } 5(83 \%) \text {, } \\
\text { in survivors: } 2(18 \%)\end{array}$ \\
\hline $\begin{array}{l}\text { Lehle (29) } \\
{[2014]}\end{array}$ & $\mathrm{n} / \mathrm{a}$ & $\begin{array}{l}\text { marker for hemoly- } \\
\text { sis: fHb first day } \\
\text { after } \\
\text { ECMO start }\end{array}$ & $\mathrm{n} / \mathrm{a}$ & $\begin{array}{c}\text { patients with multiple fHb } \\
>100 \mathrm{mg} / \mathrm{dl} \text { before ECMO } \\
\text { start were excluded from } \\
\text { the analysis }\end{array}$ & $\mathrm{n} / \mathrm{a}$ \\
\hline $\begin{array}{l}\text { Lubnow (30) } \\
\quad[2014]\end{array}$ & $\begin{array}{c}\text { acceptable on ECMO: } \\
\mathrm{fHb}<10, \mathrm{LDH}<350\end{array}$ & daily & $20(24.1 \%)^{d}$ & $\mathrm{n} / \mathrm{a}$ & $\mathrm{n} / \mathrm{a}$ \\
\hline $\begin{array}{l}\text { Lehle (31) } \\
{[2015]}\end{array}$ & $\begin{array}{c}\text { normal: } \\
\mathrm{fHb} \leq 10, \mathrm{LDH} \leq 250 \\
\text { critical: } \mathrm{fHb}>50\end{array}$ & $\begin{array}{l}\text { before and } 2 \mathrm{~h} \text { after } \\
\text { ECMO start, days } 1- \\
10 \text {, the day of and } \\
\text { one day after } \\
\text { ECMO end }\end{array}$ & $\begin{array}{l}8(2.5 \%) \text { only patients with PHT, } \\
\text { critical: } 1.7 \% \text { of all fHb-values }\end{array}$ & $\begin{array}{l}\text { patients with } \mathrm{fHb} \\
>50 \mathrm{mg} / \mathrm{dl} \text { before ECMO } \\
\text { start were excluded, } \mathrm{fHb} \\
\text { und LDH did not change } \\
\text { during ECMO therapy }\end{array}$ & $\begin{array}{c}\text { survivors: } \mathrm{fHb} \\
9.0 \mathrm{mg} / \mathrm{dl}(6.0-14.2) \text {, } \\
\text { deceased: } \mathrm{fHb} \\
14.8 \mathrm{mg} / \mathrm{dl}(9.1-25.6)\end{array}$ \\
\hline $\begin{array}{c}\text { Omar (23) } \\
{[2015]}\end{array}$ & $\begin{array}{l}\text { normal: } \mathrm{fHb} \leq 10 \text {, } \\
\text { critical: } \mathrm{fHb}>50\end{array}$ & $\begin{array}{l}\mathrm{fHb} \text { was frequently } \\
\text { checked }\end{array}$ & $\mathrm{n} / \mathrm{a}$ & $\mathrm{n} / \mathrm{a}$ & $\begin{array}{l}\text { hemolysis occurred in: } \\
80 \% \text { of deceased, } \\
0 \% \text { of survivors }\end{array}$ \\
\hline
\end{tabular}




\begin{tabular}{|c|c|c|c|c|c|}
\hline $\begin{array}{l}\text { Malfertheiner } \\
\text { (17) } \\
\text { [2016] }\end{array}$ & $\begin{array}{l}\text { normal: } \\
\mathrm{fHb}<50 \\
\mathrm{LDH}<250\end{array}$ & $\begin{array}{l}\text { before ECMO start, } \\
\text { days } 1-5 \text {, end of } \\
\text { ECMO and the day } \\
\text { after }\end{array}$ & $\begin{array}{l}\text { before ECMO start median fHb: } 48 \mathrm{mg} / \mathrm{dl}(34-81)^{\mathrm{g}}, \mathrm{LDH}: 404 \mathrm{U} / 1 \text { ( } 287- \\
574)^{\mathrm{g}} \text {, } \\
\text { day } 5 \text { median fHb: } 40 \mathrm{mg} / \mathrm{dl}(27-61)^{\mathrm{g}}, \mathrm{LDH}: 425 \mathrm{U} / \mathrm{l}(327-574)^{\mathrm{g}} \text {, } \\
\text { last day on ECMO median fHb: } 54 \mathrm{mg} / \mathrm{dl}(35-85)^{\mathrm{g}}, \mathrm{LDH}: 390 \mathrm{U} / \mathrm{l}(317- \\
528)^{\mathrm{g}} \text {, } \\
\text { the day after ECMO end median fHb: } 38 \mathrm{mg} / \mathrm{dl}(27-67)^{\mathrm{g}}, \mathrm{LDH}: 366 \mathrm{U} / 1 \\
(303-520)^{\mathrm{g}}\end{array}$ & $\begin{array}{l}\text { fHb: slight decrease after } \\
\text { ECMO start, } \\
\text { LDH: slight increase after } \\
\text { ECMO start }\end{array}$ & $\mathrm{n} / \mathrm{a}$ \\
\hline $\begin{array}{c}\text { Pan }(24) \\
{[2016]}\end{array}$ & $\begin{array}{l}\text { normal: } \mathrm{fHb}<10, \\
\text { low level: } \mathrm{fHb} 10-50, \\
\text { high level: } \mathrm{fHb}>50\end{array}$ & every 6 hours & $15(26.8 \%)^{\mathrm{h}}$ & $\mathrm{n} / \mathrm{a}$ & $\mathrm{n} / \mathrm{a}$ \\
\hline $\begin{array}{c}\text { Kon }(21) \\
{[2017]}\end{array}$ & $\mathrm{n} / \mathrm{a}$ & $\mathrm{n} / \mathrm{a}$ & $43(7.3 \%)$ & $\mathrm{n} / \mathrm{a}$ & $\mathrm{n} / \mathrm{a}$ \\
\hline $\begin{array}{l}\text { Lorusso (32) } \\
\quad[2017]\end{array}$ & $\mathrm{fHb}>50$ & $\mathrm{n} / \mathrm{a}$ & $\begin{array}{c}\text { complete study population: } 266(5.3 \%)^{\mathrm{i}} \\
\text { no CNS injury: } 241(5.2 \%) \\
\text { CNS injury: } 25(7.0 \%)\end{array}$ & $\mathrm{n} / \mathrm{a}$ & $\mathrm{n} / \mathrm{a}$ \\
\hline $\begin{array}{l}\text { Brechot (33) } \\
\quad[2018]\end{array}$ & $\begin{array}{l}\mathrm{fHb}>50, \\
\text { massive hemolysis: } \mathrm{fHb} \\
>100 \text { and clinical signs }\end{array}$ & daily & $\begin{array}{c}\text { complete study population: } 47(29.9 \%)^{\mathrm{j}},\left(\text { massive: } 13(8.3 \%)^{\mathrm{j}}\right) \text {, } \\
\text { MERT: } 38(32.2 \%) \text {, (massive: } 8(6.8 \%)) \\
\text { ICU: } 9(23.1 \%) \text {, (massive: } 5(12.8 \%))\end{array}$ & $\mathrm{n} / \mathrm{a}$ & $\mathrm{n} / \mathrm{a}$ \\
\hline $\begin{array}{l}\text { Hoshino (34) } \\
\quad[2018]\end{array}$ & $\mathrm{n} / \mathrm{a}$ & $\mathrm{n} / \mathrm{a}$ & increased hemolysis when clots occur within the ECMO-system & $\mathrm{n} / \mathrm{a}$ & $\mathrm{n} / \mathrm{a}$ \\
\hline $\begin{array}{l}\text { Mazzeffi (35) } \\
\quad[2018]\end{array}$ & $\mathrm{fHb}>50$ & $\mathrm{n} / \mathrm{a}$ & $\begin{array}{l}\text { complete study population: } 41(5.5 \%)^{k} \\
\text { 27Ch: } 17(4.6 \%) \\
\text { 31Ch: } 24(6.5 \%)\end{array}$ & $\mathrm{n} / \mathrm{a}$ & $\mathrm{n} / \mathrm{a}$ \\
\hline $\begin{array}{l}\text { Bosma (25) } \\
\quad[2019]\end{array}$ & $\begin{array}{l}\text { peak: } \mathrm{H} \text {-index }>20 \text { in } \geq 2 \\
\text { consecutive measurements, } \\
\text { normal: } \mathrm{H} \text {-Index } \leq 4\end{array}$ & $\begin{array}{l}\text { H-index: with every } \\
\text { routine clinical } \\
\text { chemistry analysis }\end{array}$ & H-index peak: $5(27.8 \%)^{1}$ & $\mathrm{n} / \mathrm{a}$ & $\mathrm{n} / \mathrm{a}$ \\
\hline $\begin{array}{l}\text { Deatrick (18) } \\
\quad[2019]\end{array}$ & $\mathrm{n} / \mathrm{a}$ & daily & $\begin{array}{l}\text { titrating }^{\mathrm{m}} \text { : median fHb: } 4.3 \mathrm{mg} / \mathrm{dl}(2.5-8.7)^{\mathrm{g}}, \mathrm{LDH}: 808 \mathrm{U} / \mathrm{l}(727-1112)^{\mathrm{g}} \text {, } \\
\text { weight-based }^{\mathrm{n}} \text { : median fHb: } 4.3 \mathrm{mg} / \mathrm{dl}(3.0-7.3)^{\mathrm{g}} \text {, LDH: } 940 \mathrm{U} / 1(809-1137)^{\mathrm{g}}\end{array}$ & $\mathrm{n} / \mathrm{a}$ & $\mathrm{n} / \mathrm{a}$ \\
\hline $\begin{array}{l}\text { Fisser (20) } \\
\text { [2019] }\end{array}$ & $\mathrm{n} / \mathrm{a}$ & $\mathrm{n} / \mathrm{a}$ & $\begin{array}{l}\text { thrombosis: mean fHb: } 67 \mathrm{mg} / \mathrm{dl}( \pm 94)^{\circ} \\
\text { no thrombosis: mean fHb: } 56 \mathrm{mg} / \mathrm{dl}( \pm 37)^{\circ}\end{array}$ & $\mathrm{n} / \mathrm{a}$ & $\mathrm{n} / \mathrm{a}$ \\
\hline
\end{tabular}

Table 3. Pump head thrombosis, pump flow und extracorporeal circuit

\begin{tabular}{|c|c|c|c|c|}
\hline \multirow[b]{2}{*}{ Study [year] } & \multirow[b]{2}{*}{ PHT (n) } & \multirow[b]{2}{*}{ Pump flow [1/min] } & \multicolumn{2}{|c|}{ Extracorporeal circuit } \\
\hline & & & pump model $(\mathrm{n})$ & vv-cannulation $(\mathrm{n})$ \\
\hline $\begin{array}{c}\text { Chan (26) } \\
{[2010]}\end{array}$ & $\begin{array}{l}\text { no } \\
\text { equipment } \\
\text { failure }\end{array}$ & initially: $2.5-5.7^{\mathrm{a}}$ & $7(100 \%)$ centrifugal pumps & $\begin{array}{c}\text { SLC: DC: } 21-23 \mathrm{Ch} \text { femoral vein, } \\
\text { IC: } 18-21 \mathrm{Ch} \text { femoral vein, } 15-17 \mathrm{Ch} \text { internal jugular vein }\end{array}$ \\
\hline $\begin{array}{l}\text { Petersen (22) } \\
\quad[2011]\end{array}$ & $\mathrm{n} / \mathrm{a}$ & $\begin{array}{c}\mathrm{n} / \mathrm{a} \\
2\end{array}$ & Maquet Rotaflow ${ }^{\mathrm{b}}$ & $\mathrm{n} / \mathrm{a}$ \\
\hline $\begin{array}{l}\text { Chimot (19) } \\
{[2013]}\end{array}$ & $\mathrm{n} / \mathrm{a}$ & $\begin{array}{l}\text { 20Ch: } 2.175( \pm 0.556)^{\mathrm{c}} \text {, } \\
\text { 23Ch: } 3.207( \pm 0.653)^{\mathrm{c}} \text {, } \\
\text { 27Ch: } 3.963( \pm 0.729)^{\mathrm{c}} \text {, } \\
\text { 31Ch: } 5.490( \pm 0.984)^{\mathrm{c}}\end{array}$ & $\mathrm{n} / \mathrm{a}$ & DLC: $52(100 \%)$ Avalon $20-31 \mathrm{Ch}$ \\
\hline $\begin{array}{l}\text { Guirand (27) } \\
\quad[2014]\end{array}$ & $\mathrm{n} / \mathrm{a}$ & $\mathrm{n} / \mathrm{a}$ & Sorin SIII roller pump & $\begin{array}{l}\text { DLC: Avalon, } \\
\text { SLC: DC: femoral vein, IC: internal jugular vein }\end{array}$ \\
\hline $\begin{array}{l}\text { Kutlesa (28) } \\
\quad[2014]\end{array}$ & $\begin{array}{l}\text { possibly } \\
\text { up to } \\
7(41 \%)^{d}\end{array}$ & $\mathrm{n} / \mathrm{a}$ & $17(100 \%)$ Medtronic Biomedicus BP80 ${ }^{b}$ & $\begin{array}{c}\text { SLC: } 14(82.4 \%)^{\mathrm{h}} \text { femoro-jugular, } 3(17.6 \%)^{\mathrm{h}} \text { femoro-femoral, } \\
\text { overage DC: } 23 \mathrm{Ch}, \text { IC: } 21 \mathrm{Ch}, \\
\text { q average DC: } 21 \mathrm{Ch}, \text { IC: } 19 \mathrm{Ch}\end{array}$ \\
\hline $\begin{array}{l}\text { Lehle (29) } \\
\text { [2014] }\end{array}$ & $\begin{array}{l}1(0.5 \%) \\
\text { was } \\
\text { excluded } \\
\text { from } \\
\text { analysis }\end{array}$ & $\begin{array}{l}\text { increased pump flow does not } \\
\text { lead to elevated median } \mathrm{fHb}^{\mathrm{e}}\end{array}$ & $\begin{array}{c}97(52.2 \%) \text { Maquet Rotaflow }{ }^{\mathrm{b}} \text {, fHb: } 49 \mathrm{mg} / \mathrm{dl}(34-75)^{\mathrm{f}}, \\
36(19.4 \%) \text { Maquet Rotassist }{ }^{\mathrm{b}} \text {, fHb: } 47 \mathrm{mg} / \mathrm{dl}(30-67)^{\mathrm{f}}, \\
36(19.4 \%) \text { Medos Deltastream }{ }^{\mathrm{g}} \text {, fHb: } 37 \mathrm{mg} / \mathrm{dl}(30-55)^{\mathrm{f}}, \\
17(9.1 \%) \text { Sorin Revolution }\end{array}$ & $\begin{array}{c}\text { DLC: } 7(3.8 \%)^{\mathrm{h}} \text { NovaPort } 24 \mathrm{Ch}, 20(10.8 \%)^{\mathrm{h}} \text { Avalon } 23 \mathrm{Ch}, \\
21(11.3 \%)^{\mathrm{h}} \text { Avalon } 27 \mathrm{Ch}, \\
\text { SLC: DC: } 71(38.2 \%)^{\mathrm{h}} 21 \mathrm{Ch}, 67(36.0 \%)^{\mathrm{h}} 23 \mathrm{Ch}, \\
\text { IC: } 18(9.7 \%)^{\mathrm{h}} 15 \mathrm{Ch}, 97(52.2 \%)^{\mathrm{h}} 17 \mathrm{Ch}, 11(5.9 \%)^{\mathrm{h}} 19 \mathrm{Ch}, 12(6.5 \%)^{\mathrm{h}} \\
21 \mathrm{Ch}\end{array}$ \\
\hline $\begin{array}{l}\text { Lubnow (30) } \\
{[2014]}\end{array}$ & $13(4.9 \%)^{\mathrm{i}}$ & initially approximately $1.5-2$ & $\begin{array}{l}116(43.8 \%) \text { Maquet Rotaflow } \\
51(19.2 \%) \text { Maquet Rotassist } \\
47(17.7 \%) \text { Medos Deltastream } \\
\text {, } \\
36(13.6 \%) \text { Sorin Revolution } \\
15(5.7 \%) \text { Novalung iLA Active }\end{array}$ & $\begin{array}{c}\text { DLC: } 19(7.2 \%)^{\mathrm{h}} \text { NovaPort, } 55(20.8 \%)^{\mathrm{h}} \text { Avalon, } \\
\text { SLC: } 191(72.1 \%)^{\mathrm{h}}\end{array}$ \\
\hline $\begin{array}{l}\text { Lehle (31) } \\
\text { [2015] }\end{array}$ & $\begin{array}{l}8(2.5 \%) \\
\text { were } \\
\text { excluded } \\
\text { from further } \\
\text { analysis }\end{array}$ & $\begin{array}{c}\text { low } \leq 2.5: \\
\mathrm{fHb} 5.2 \mathrm{mg} / \mathrm{dl}(3.5-8.1)^{\mathrm{f}} \\
\text { medium } 2.6-2.9: \\
\mathrm{fHb} 5.3 \mathrm{mg} / \mathrm{dl}(3.6-8.1)^{\mathrm{f}} \\
\mathrm{high} \geq 3.0: \\
\mathrm{fHb} 6.4 \mathrm{mg} / \mathrm{dl}(4.3-10.1)^{\mathrm{f}}\end{array}$ & $\begin{array}{c}117(36.8 \%) \text { Maquet Rotaflow }, \text { fHb: } 6 \mathrm{mg} / \mathrm{dl}(3.8- \\
10.2)^{\mathrm{f}}, \\
64 \text { (20.1\%) Maquet Rotassist }, \text { fHb: } 5.2 \mathrm{mg} / \mathrm{dl}(3.5-7.8)^{\mathrm{f}}, \\
85(26.7 \%) \text { Medos Deltastream } \\
8.0)^{\mathrm{f}}, \mathrm{fHb}: 5.3 \mathrm{mg} / \mathrm{dl}(3.6- \\
52 \text { (16.4\%) Sorin Revolution }{ }^{\mathrm{b}}, \mathrm{fHb}: 5.8 \mathrm{mg} / \mathrm{dl}(3.8-9.1)^{\mathrm{f}}\end{array}$ & 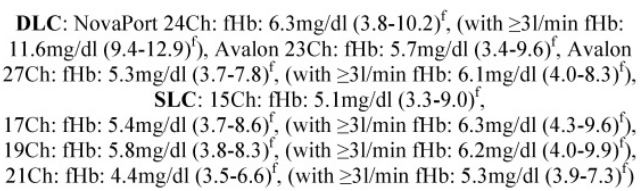 \\
\hline $\begin{array}{l}\text { Omar }(23) \\
{[2015]}\end{array}$ & $\mathrm{n} / \mathrm{a}$ & $\mathrm{n} / \mathrm{a}$ & $\begin{array}{l}\text { Medtronic Biomedicus BP80 } \\
\text { Thoratec Centrimag }\end{array}$ & $\mathrm{n} / \mathrm{a}$ \\
\hline $\begin{array}{l}\text { Malfertheiner } \\
\text { (17) } \\
{[2016]}\end{array}$ & $\begin{array}{l}\text { none } \\
\text { reported }\end{array}$ & days 1-5: $2.58( \pm 0.571)^{\mathrm{c}}$ & $\begin{array}{l}18(33.3 \%) \text { Maquet Rotassist }{ }^{\mathrm{b}} \text {, } \\
18(33.3 \%) \text { Medos Deltastream } \\
18(33.3 \%) \text { Sorin Revolution } \\
\text { b }\end{array}$ & $\begin{array}{c}\text { DLC: } 10(18.5 \%)^{\mathrm{h}} \text { Avalon, } 3(5.6 \%)^{\mathrm{h}} \text { NovaPort, } \\
\text { SLC: } 41(75.9 \%)^{\mathrm{h}}\end{array}$ \\
\hline
\end{tabular}




\begin{tabular}{|c|c|c|c|c|}
\hline $\begin{array}{c}\text { Pan }(24) \\
{[2016]}\end{array}$ & $5(8.9 \%)^{j}$ & $\begin{array}{c}\text { normal }^{\mathrm{k}}: 3.76(3.12-4.34)^{\mathrm{f}}, \\
\text { low level } \\
\text { high level }^{\mathrm{m}}: 3.83(3.15-4.45)^{\mathrm{f}} \text {, } \\
\text {, } 3.14-4.14)^{\mathrm{f}}\end{array}$ & $\begin{array}{l}\text { Maquet Rotaflow }{ }^{\mathrm{b}} \text {, } \\
\text { Maquet Rotassist }^{\mathrm{b}}\end{array}$ & $\begin{array}{l}\text { SLC: DC: } 21-25 \mathrm{Ch} \text { femoral vein, IC: } 21-25 \mathrm{Ch} \text { femoral vein, } \\
\text { (additionally for high blood flow: } 17-19 \mathrm{Ch} \text { right jugular vein) }\end{array}$ \\
\hline $\begin{array}{c}\text { Kon }(21) \\
{[2017]}\end{array}$ & $\mathrm{n} / \mathrm{a}$ & $\begin{array}{l}\text { vv: initially: } 4.0(3.2-4.7)^{\mathrm{f}} \\
\text { at } 24 \mathrm{~h}: 4.1(3.3-4.8)^{\mathrm{f}}\end{array}$ & $\mathrm{n} / \mathrm{a}$ & $\begin{array}{l}\text { DLC: } 319(54.0 \%)^{\mathrm{n}} \text {, } \\
\text { SLC: } 231(39.1 \%)^{\mathrm{n}}\end{array}$ \\
\hline $\begin{array}{l}\text { Lorusso (32) } \\
\quad[2017]\end{array}$ & $\mathrm{n} / \mathrm{a}$ & $\begin{array}{c}\text { no CNS injury at } 4 \mathrm{~h}: 4.0( \pm 1.0)^{\mathrm{c}}, \\
\text { at } 24 \mathrm{~h}: 4.0( \pm 1.1)^{\mathrm{c}}, \\
\mathrm{CNS} \text { injury at } 4 \mathrm{~h}: 4.1( \pm 1.0)^{\mathrm{c}}, \\
\text { at } 24 \mathrm{~h}: 4.1( \pm 1.0)^{\mathrm{c}}\end{array}$ & $\mathrm{n} / \mathrm{a}$ & $\mathrm{n} / \mathrm{a}$ \\
\hline $\begin{array}{l}\text { Brechot (33) } \\
\quad[2018]\end{array}$ & $\mathrm{n} / \mathrm{a}$ & $\mathrm{n} / \mathrm{a}$ & $\mathrm{n} / \mathrm{a}$ & $\begin{array}{l}\text { SLC: MERT: DC 24Ch }(24-25)^{\mathrm{f}} \text {, IC } 18 \mathrm{Ch}(17-19)^{\mathrm{f}} \text {, } \\
\text { ICU: DC } 24 \mathrm{Ch}(24-25)^{\mathrm{f}} \text {, IC 18Ch }(17-19)^{\mathrm{f}} \text {, }\end{array}$ \\
\hline $\begin{array}{l}\text { Hoshino (34) } \\
\quad[2018]\end{array}$ & $\begin{array}{l}6 \text { clots in } \\
\text { unknown } \\
\text { locations }\end{array}$ & $\mathrm{n} / \mathrm{a}$ & $\mathrm{n} / \mathrm{a}$ & $\mathrm{n} / \mathrm{a}$ \\
\hline $\begin{array}{l}\text { Mazzeffi (35) } \\
\quad[2018]\end{array}$ & $\mathrm{n} / \mathrm{a}$ & $\begin{array}{l}27 \mathrm{Ch} \text { at } 4 \mathrm{~h}: 4.2(3.7-4.7)^{\mathrm{f}}, \\
\text { at } 24 \mathrm{~h}: 4.2(3.8-4.75)^{\mathrm{f}}, \\
31 \mathrm{Ch} \text { at } 4 \mathrm{~h}: 4.2(3.6-4.8)^{\mathrm{f}}, \\
\text { at } 24 \mathrm{~h}: 4.3(3.8-4.9)^{\mathrm{f}}\end{array}$ & $\mathrm{n} / \mathrm{a}$ & DLC: $372(50 \%) 27 \mathrm{Ch}, 372(50 \%) 31 \mathrm{Ch}$ \\
\hline $\begin{array}{l}\text { Bosma (25) } \\
{[2019]}\end{array}$ & $\begin{array}{l}\text { H-index } \\
>100 \text { when } \\
\text { PHT } \\
\text { occurred }\end{array}$ & $\mathrm{n} / \mathrm{a}$ & $\mathrm{n} / \mathrm{a}$ & $\mathrm{n} / \mathrm{a}$ \\
\hline $\begin{array}{l}\text { Deatrick (18) } \\
\quad[2019]\end{array}$ & $\mathrm{n} / \mathrm{a}$ & $\begin{array}{l}\text { typically at this medical center: } \\
\qquad 4-5\end{array}$ & Maquet Rotaflow ${ }^{\mathrm{b}}$ & $\begin{array}{l}\text { SLC: DC: } 23-25 \mathrm{Ch} \text { femoral vein, } \\
\text { IC: } 21-23 \mathrm{Ch} \text { right internal jugular vein }\end{array}$ \\
\hline $\begin{array}{l}\text { Fisser (20) } \\
{[2019]}\end{array}$ & $\mathrm{n} / \mathrm{a}$ & $>2.5$ & $\mathrm{n} / \mathrm{a}$ & $\begin{array}{c}\text { DLC: } 19(11.0 \%)^{\mathrm{h}} \text { jugular vein, } 12(7.0 \%)^{\mathrm{h}} \text { femoral vein, } \\
\text { SLC: } 141(82.0 \%)^{\mathrm{h}}\end{array}$ \\
\hline
\end{tabular}

\section{Discussion}

This systematic review includes 19 publications on adult ARDS patients treated with VV ECMO and associated intravascular hemolysis. The reported incidence of hemolysis varied greatly among the different studies. Hemolysis occurred more frequently in non-survivors compared to survivors of an ARDS and therapy with VV ECMO [22, 23, 26, 28, 31]. All reported cases of a pump head thrombosis were accompanied by hemolysis [24, 25, 28-31, 34]. The use of centrifugal- or diagonal-pump-systems had no, a high blood flow ( $\geq 31 / \mathrm{min}$ ) had only a minimal effect on the occurrence of hemolysis [17, 29, 31]. However, using a dual-lumen NovaPort-24Chcannula with high blood flow was associated with a significantly higher rate of hemolysis compared to the use of larger cannulas [31].

There were only two studies with a prospective study design [17, 18]. Therefore, there is only a relatively low level of evidence describing an association between hemolysis and therapy with $\mathrm{VV}$ ECMO and it is unclear whether the ECMO is the reason for the damage of the red blood cells. In addition, the survey of Chimot and colleagues might suffer from a recall bias since data collection was done retrospectively [19].

The prospective study performed by Deatrick et al. only included ten patients. Because it was a pilot study, the authors did not perform a sample size calculation [18]. Malfertheiner and colleagues expected an adequate statistical power with a sample size of 18 patients per group. Nevertheless, a statistical power calculation was not performed a priori. In addition, inclusion criteria required a minimum duration of five days of therapy with $\mathrm{VV}$ ECMO. However, at least one patient of one 18-patient cohort received VV ECMO only for four days [17].

Kurtlesa and colleagues published an exceptionally high hemolysis incidence of $41 \%$, which might be influenced by the small number of included patients $(n=17)$ [28]. With a hemolysis incidence of $5 \%$ the recently publishes EOLIA-trial is within the common range [4]. However, hemolysis was defined differently among the studies: A significant number of studies did not define a critical threshold for hemolysis or did not report any data on fHb-concentrations [19-22, 26, 29, 34]. Whether the blood hemoglobin concentration or transfusion requirements are helpful parameters to estimate the degree of hemolysis remains questionable [19]. In addition, transfusion of red blood cells itself can increase circulating levels of $\mathrm{fHb}$ especially when packed red blood cells are transfused that are near the end of the allowed storage duration [36, 37].

The search strategy of this systematic review considered all work published in MEDLINE, Web of Science and EMBASE. Because almost all included studies followed a retrospective study design, this review is limited to only report an association between hemolysis and therapy with VV ECMO but cannot claim a causal link between both entities. This systematic review is further limited by the heterogenic nature of the included studies. There was a wide variety of inclusion and exclusion criteria, 
sample sizes, time on and indication for ECMO, definition and quantification of hemolysis and measured endpoints. In most studies, male sex dominated the groups of included patients. Lubnow et al. included only patients that received a complete change of the ECMO-circuit during therapy with VV ECMO [30]. Both studies of Lehle and colleagues excluded patients with hemolysis before ECMO therapy. However, the threshold for plasma concentrations of cell-free hemoglobin before therapy with VV ECMO was different in both studies [29, 31]. Furthermore, patients with significant hemolysis during ECMO therapy were excluded when a cause for increased red blood cell break down such as a pump head thrombosis was considered evident [29, 31]. For this systematic review the effects and strategies of anticoagulation during VV ECMO therapy that might have an impact on development of a pump head thrombosis were not analyzed. Additionally, it is known that hemolysis can be caused by high negative pressure within the drainage cannula [38]. The negative pressure is linked to the small cannula size, high blood flow and patient specific factors. However, these connections were not investigated in this review. The study by Guirand et al. allowed inclusion of patients from the age of 16 [27]. Furthermore, from the data reported in the study by Hoshino et al. it is unclear whether truly only adults were included [34]. Moreover, this review is limited by including different papers that accessed the same databases. Therefore, several papers may have reported data on the same set of patients $[17,20,21$, 29-32, 35]. A meta-analysis of the studies with data from patients treated with VV ECMO and with a unique definition and severity grading of hemolysis might be necessary to obtain reliable information on the incidence of hemolysis during therapy with VV ECMO and whether hemolysis during therapy with VV ECMO might affect mortality in patients with severe ARDS.

Taken together, this systematic review indicated that hemolysis might be a frequent complication associated with VV ECMO therapy in severe ARDS $[19,24-26,28,30,33]$. Nevertheless, especially the studies providing data on large VV ECMO populations reported incidences of hemolysis of less than $10 \%$ [21, 32, 35]. In addition, there is emerging evidence that hemolysis might be associated with increased mortality during therapy with VV ECMO $[22,23,26,28,31]$. It seems that in today's common VV ECMO-systems the pump model, cannulas and blood flow do not have a significant impact on the development of a hemolysis [17, 29, 31]. On the other hand, various systemic diseases like ARDS or sepsis are associated with a certain degree of hemolysis [9,
10, 39]. Whether hemolysis associated with VV ECMO therapy increases the side effects of $\mathrm{fHb}$ on systemic inflammation and end organ damage or whether therapy of the underlying disease using VV ECMO helps to reduce the total amount of circulating intravascular cell-free hemoglobin is unclear.

A prospective study that includes measurements for $\mathrm{fHb}$-levels before the start of VV ECMO therapy, the quality and number of transfused red blood cell concentrates, and additional hemolysis markers such as haptoglobin or lactate dehydrogenase activity would be warranted. Such a study would clarify if VV ECMO-induced hemolysis clearly exceeds the levels of $\mathrm{fHb}$ that are released in patients with ARDS but not treated with ECMO. In addition, a prospective trial could also address whether hemolysis is just a marker of disease severity and mortality in patients with ARDS and VV ECMO therapy or whether hemolysis and the toxic effects of $\mathrm{fHb}$ might be relevant cofactors for disease progression. For the latter, treatment options could be developed that include scavenging and reduction of increased plasma concentrations of cell-free hemoglobin.

\section{Acknowledgements}

We acknowledge support from the German Research Foundation (DFG) and the Open Access Publication Fund of Charité - Universitätsmedizin Berlin.

\section{Funding}

This research received no external funding. Dr. Graw is participant in the BIH-Charite Clinician Scientist Program funded by the Charite Universitätsmedizin Berlin and the Berlin Institute of Health.

\section{Competing Interests}

The authors have declared that no competing interest exists.

\section{References}

1. Bellani G, Laffey JG, Pham T, Fan E, Brochard L, Esteban A, Gattinoni L, van Haren F, Larsson A, McAuley DF et al: Epidemiology, Patterns of Care, and Mortality for Patients With Acute Respiratory Distress Syndrome in Intensive Care Units in 50 Countries. Jama 2016, 315(8):788-800.

2. Noah MA, Peek GJ, Finney SJ, Griffiths MJ, Harrison DA, Grieve R, Sadique MZ, Sekhon JS, McAuley DF, Firmin RK et al: Referral to an extracorporeal membrane oxygenation center and mortality among patients with severe 2009 influenza A(H1N1). Jama 2011, 306(15):1659-1668.

3. Peek GJ, Mugford M, Tiruvoipati R, Wilson A, Allen E, Thalanany MM, Hibbert CL, Truesdale A, Clemens F, Cooper N et al: Efficacy and economic assessment of conventional ventilatory support versus extracorporeal membrane oxygenation for severe adult respiratory failure (CESAR): a multicentre randomised controlled trial. Lancet 2009, 374(9698):1351-1363.

4. Combes A, Hajage D, Capellier G, Demoule A, Lavoue S, Guervilly C, Da Silva D, Zafrani L, Tirot P, Veber B et al: Extracorporeal Membrane Oxygenation for Severe Acute Respiratory Distress Syndrome. The New England journal of medicine 2018, 378(21):1965-1975.

5. Zangrillo A, Landoni G, Biondi-Zoccai G, Greco M, Greco T, Frati G, Patroniti $\mathrm{N}$, Antonelli M, Pesenti A, Pappalardo F: A meta-analysis of complications and mortality of extracorporeal membrane oxygenation. Critical care and 
resuscitation: journal of the Australasian Academy of Critical Care Medicine 2013, 15(3):172-178.

6. Hemmila MR, Rowe SA, Boules TN, Miskulin J, McGillicuddy JW, Schuerer DJ, Haft JW, Swaniker F, Arbabi S, Hirschl RB et al: Extracorporeal life support for severe acute respiratory distress syndrome in adults. Ann Surg 2004, 240(4):595-605.

7. Schmidt M, Pellegrino V, Combes A, Scheinkestel C, Cooper DJ, Hodgson C: Mechanical ventilation during extracorporeal membrane oxygenation. Crit Care 2014, 18(1):203

8. Ventetuolo CE, Muratore CS: Extracorporeal life support in critically ill adults. Am J Respir Crit Care Med 2014, 190(5):497-508.

9. Adamzik M, Hamburger T, Petrat F, Peters J, de Groot H, Hartmann M: Free hemoglobin concentration in severe sepsis: methods of measurement and prediction of outcome. Crit Care 2012, 16(4):R125.

10. Lin T, Maita D, Thundivalappil SR, Riley FE, Hambsch J, Van Marter LJ, Christou HA, Berra L, Fagan S, Christiani DC et al: Hemopexin in severe inflammation and infection: mouse models and human diseases. Crit Care 2015, 19:166.

11. Shaver CM, Upchurch CP, Janz DR, Grove BS, Putz ND, Wickersham NE, Dikalov SI, Ware LB, Bastarache JA: Cell-free hemoglobin: a novel mediator of acute lung injury. Am J Physiol Lung Cell Mol Physiol 2016, 310(6):L532-541.

12. Villagra J, Shiva S, Hunter LA, Machado RF, Gladwin MT, Kato GJ: Platelet activation in patients with sickle disease, hemolysis-associated pulmonary hypertension, and nitric oxide scavenging by cell-free hemoglobin. Blood 2007, 110(6):2166-2172

13. Balla G, Jacob HS, Eaton JW, Belcher JD, Vercellotti GM: Hemin: a possible physiological mediator of low density lipoprotein oxidation and endothelial injury. Arteriosclerosis and thrombosis: a journal of vascular biology 1991, 11(6):1700-1711

14. Lin T, Kwak YH, Sammy F, He P, Thundivalappil S, Sun G, Chao W, Warren HS: Synergistic inflammation is induced by blood degradation products with microbial Toll-like receptor agonists and is blocked by hemopexin. J Infect Dis 2010, 202(4):624-632

15. von Elm E, Altman DG, Egger M, Pocock SJ, Gotzsche PC, Vandenbroucke JP: The Strengthening the Reporting of Observational Studies in Epidemiology (STROBE) statement: guidelines for reporting observational studies. Lancet 2007, 370(9596):1453-1457.

16. Schulz KF, Altman DG, Moher D: CONSORT 2010 Statement: Updated guidelines for reporting parallel group randomised trials. Journal of clinical epidemiology 2010, 63(8):834-840.

17. Malfertheiner MV, Philipp A, Lubnow M, Zeman F, Enger TB, Bein T, Lunz D, Schmid C, Muller T, Lehle K: Hemostatic Changes During Extracorporeal Membrane Oxygenation: A Prospective Randomized Clinical Trial Comparing Three Different Extracorporeal Membrane Oxygenation Systems. Critical care medicine 2016, 44(4):747-754.

18. Deatrick KB, Galvagno SM, Mazzeffi MA, Kaczoroswki DJ, Herr DL, Rector R, Hochberg E, Rabinowitz RP, Scalea TM, Menaker J: Pilot study evaluating a non-titrating, weight-based anticoagulation scheme for patients on veno-venous extracorporeal membrane oxygenation. Perfusion. 2019.

19. Chimot L, Marque S, Gros A, Gacouin A, Lavoue S, Camus C, Le Tulzo Y: Avalon(c) bicaval dual-lumen cannula for venovenous extracorporeal membrane oxygenation: survey of cannula use in France. ASAIO journal 2013, 59(2):157-161.

20. Fisser C, Reichenbacher C, Muller T, Schneckenpointner R, Malfertheiner MV, Philipp A, Foltan M, Lunz D, Zeman F, Lubnow M: Incidence and Risk Factors for Cannula-Related Venous Thrombosis After Venovenous Extracorporeal Membrane Oxygenation in Adult Patients With Acute Respiratory Failure. Critical care medicine 2019, 47(4):e332-e339.

21. Kon ZN, Bittle GJ, Pasrija C, Pham SM, Mazzeffi MA, Herr DL, Sanchez PG, Griffith BP: Venovenous Versus Venoarterial Extracorporeal Membrane Oxygenation for Adult Patients With Acute Respiratory Distress Syndrome Requiring Precannulation Hemodynamic Support: A Review of the ELSO Registry. The Annals of thoracic surgery 2017, 104(2):645-649.

22. Petersen E, Keld DB, Ellermann-Eriksen S, Gubbels S, Ilkjaer S, Jensen-Fangel $\mathrm{S}$, Lindskov C: Failure of combination oral oseltamivir and inhaled zanamivir antiviral treatment in ventilator- and ECMO-treated critically ill patients with pandemic influenza A (H1N1)v. Scand J Infect Dis 2011, 43(6-7):495-503.

23. Omar HR, Mirsaeidi M, Socias S, Sprenker C, Caldeira C, Camporesi EM, Mangar D: Plasma Free Hemoglobin Is an Independent Predictor of Mortality among Patients on Extracorporeal Membrane Oxygenation Support. PloS one 2015, 10(4):e0124034

24. Pan KC, McKenzie DP, Pellegrino V, Murphy D, Butt W: The meaning of a high plasma free haemoglobin: retrospective review of the prevalence of haemolysis and circuit thrombosis in an adult ECMO centre over 5 years. Perfusion 2016, 31(3):223-231.

25. Bosma M, Waanders F, Van Schaik HP, Van Loon D, Rigter S, Scholten E, Hackeng CM: Automated and cost-efficient early detection of hemolysis in patients with extracorporeal life support: Use of the hemolysis-index of routine clinical chemistry platforms. Journal of critical care 2019, 51:29-33.

26. Chan KKC, Lee KL, Lam PKN, Law KI, Joynt GM, Yan WW: Hong Kong's experience on the use of extracorporeal membrane oxygenation for the treatment of influenza A (H1N1). Hong Kong Med J 2010, 16(6):447-454.

27. Guirand DM, Okoye OT, Schmidt BS, Mansfield NJ, Aden JK, Martin RS, Cestero RF, Hines MH, Pranikoff T, Inaba K et al: Venovenous extracorporeal life support improves survival in adult trauma patients with acute hypoxemic respiratory failure: A multicenter retrospective cohort study. J Trauma Acute Care Surg 2014, 76(5):1275-1281

28. Kutlesa M, Novokmet A, Josipovic Mraovic R, Filar B, Mardesic P, Barsic B: Extracorporeal membrane oxygenation treatment for H1N1-induced acute respiratory distress syndrome (ARDS): results of the Croatian Referral Center for Respiratory ECMO. The International journal of artificial organs 2014, 37(10):748-752.

29. Lehle K, Philipp A, Muller T, Schettler F, Bein T, Schmid C, Lubnow M: Flow dynamics of different adult ECMO systems: a clinical evaluation. Artificial organs 2014, 38(5):391-398.

30. Lubnow M, Philipp A, Foltan M, Bull Enger T, Lunz D, Bein T, Haneya A, Schmid C, Riegger G, Muller $\mathrm{T}$ et al: Technical complications during veno-venous extracorporeal membrane oxygenation and their relevance predicting a system-exchange--retrospective analysis of 265 cases. PloS one 2014, 9(12):e112316.

31. Lehle K, Philipp A, Zeman F, Lunz D, Lubnow M, Wendel HP, Gobolos L, Schmid C, Muller T: Technical-Induced Hemolysis in Patients with Respiratory Failure Supported with Veno-Venous ECMO - Prevalence and Risk Factors. PloS one 2015, 10(11):e0143527.

32. Lorusso R, Gelsomino S, Parise O, Di Mauro M, Barili F, Geskes G, Vizzardi E, Rycus PT, Muellenbach R, Mueller $\mathrm{T}$ et al: Neurologic injury in adults supported with veno-venous extracorporeal membrane oxygenation for respiratory failure: Findings from the extracorporeal life support organization database. Critical care medicine 2017, 45(8):1389-1397.

33. Brechot N, Mastroianni C, Schmidt M, Santi F, Lebreton G, Hoareau AM, Luyt CE, Chommeloux J, Rigolet M, Lebbah $S$ et al: Retrieval of severe acute respiratory failure patients on extracorporeal membrane oxygenation: Any impact on their outcomes? J Thorac Cardiovasc Surg 2018, 155(4):1621-1629.

34. Hoshino K, Muranishi K, Kawano Y, Hatomoto H, Yamasaki S, Nakamura Y, Ishikura H: Soluble fibrin is a useful marker for predicting extracorporeal membrane oxygenation circuit exchange because of circuit clots. Journal of artificial organs: the official journal of the Japanese Society for Artificial Organs 2018, 21(2):196-200.

35. Mazzeffi M, Kon Z, Menaker J, Johnson DM, Parise O, Gelsomino S, Lorusso R, Herr D: Large Dual-Lumen Extracorporeal Membrane Oxygenation Cannulas Are Associated with More Intracranial Hemorrhage. ASAIO journal. 2018.

36. Vermeulen Windsant IC, de Wit NC, Sertorio JT, Beckers EA, Tanus-Santos JE, Jacobs MJ, Buurman WA: Blood transfusions increase circulating plasma free hemoglobin levels and plasma nitric oxide consumption: a prospective observational pilot study. Crit Care 2012, 16(3):R95.

37. Donadee C, Raat NJ, Kanias T, Tejero J, Lee JS, Kelley EE, Zhao X, Liu C, Reynolds H, Azarov I et al: Nitric oxide scavenging by red blood cell microparticles and cell-free hemoglobin as a mechanism for the red cell storage lesion. Circulation 2011, 124(4):465-476.

38. Toomasian JM, Bartlett RH: Hemolysis and ECMO pumps in the 21st Century. Perfusion 2011, 26(1):5-6.

39. Janz DR, Bastarache JA, Peterson JF, Sills G, Wickersham N, May AK, Roberts LJ, 2nd, Ware LB: Association between cell-free hemoglobin, acetaminophen, and mortality in patients with sepsis: an observational study. Crit Care Med 2013, 41(3):784-790. 